\title{
Stress Induced in Low Carbon Steel Tubes of Kids Bicycle Upon Impact
}

\author{
D. Venkatrama Raju, J. Kannan
}

\begin{abstract}
The market environment is characterized by keen competition, an oversupply of goods, rapidly shifting tastes and a high rate of product innovation ad obsolescence. The long term profitability or the very survival of a company depends on new products and on commitments to continuous product innovation. Firms are seeking differential advantage and their actions continue to segment large market into smaller sub-segments. There is often a back and forth action between market reconsolidation based on innovation and fragmentation based on competition.

Keywords :Customer Perception, BSA, Ladybird Bicycles.
\end{abstract}

\section{INTRODUCTION}

Consumer experience and perception surveys are needed to help the company determine either to enhance current products or their services. The study supports an indicator of the specific level of consumer knowledge and understanding.. It also specifies the specific factors influencing their purchase decision and gives room for suggestions towards the increasing the level of satisfaction among the users of cycles.[1]-[3]

\section{SCOPE OF THE STUDY}

The study would pave way for understanding what the customers feel about the price of BSA Lady Bird cycles and its affordability s that the company can make changes in the pricing strategy, if necessary.

Out of the ranking done, the study highlights the most important factor influencing the purchase decision, so that the company can revamp its marketing strategy to retain its existing customers.

The study would enable the organization to know what factors influence the purchase decision even from the prospective customers, thereby providing a platform for attracting new customers.

The suggestions and recommendations given out by the customers would help the company to understand their mindset thereby giving room for improvement.[4]-[7]

\section{OBJECTIVE OF THE STUDY}

Primary Objective:

Revised Manuscript Received on December 30, 2019.

D. Venkatrama Raju , Professor \& Head, Department Of Science \& Humanities,Bharath Institution Of Higher Education And Research TamilNadu,India Email prof.dvraju@gmail.com

J. Kannan, Associate Professor, Department Of Science \& Humanities,Bharath Institution Of Higher Education And Research TamilNadu,India Email sjkannan1986@gmail.com
To study the market dynamics and customer perception of BSA Lady Bird cycles

Secondary objective:

To study the market scenario of cycle industry.

To find out-

Purchase behavior/ usage and attitude of customers.

Brand perception.

Brand awareness.

Brand image.

Brand satisfaction.

\section{RESEARCH TYPE:}

The type of study carried out in this project is Illustrative in nature.

Descriptive research includes surveys and fact-finding enquiries of different kinds. The major purpose of descriptive research is description of the state of affairs, as it exists at present. In social science and business research we quite often use the tern Ex post facto research for descriptive research studies.

\section{DATA COLLECTION METHODS}

Primary data processing is where the data are obtained for the first time: it is also known as fresh data, which is of an original nature. In this study, surveys are used to obtain first-hand customer data.

\section{A.Sampling Design:}

A sample design is a definite plan for obtaining a sample from a given population. It refers to the technique or the procedure the researcher would adopt in selecting items for the sample. Sampling may be defined as "the selection of some part of an aggregate or totality on the basis of which a judgment or inference about the aggregate or totality is made" [5]-[8]

\section{B.Sample}

A part of the population, or a subset from a set of units, which is provided by some process or other, usually by deliberated section with the object of investigating the properties of the parent population, or set.

C.Sample surveys:

A surveys, which is carried out using a sampling method, i.e., in which a proportion only, and not the whole population is surveyed. 


\section{Stress Induced in Low Carbon Steel Tubes of Kids Bicycle Upon Impact}

\section{AREA SAMPLING}

Area sampling is a multi- stage sampling in which maps, rather than lists are used as the sampling frame. In this method, the overall areas to be covered in a surveys are divided onto several smaller areas within a random sample is selected. In this research this method was adopted and samples were collected from areas like: Anna Nagar, Broad way, T. Nagar, Kelly's etc.[9]-13]

\section{SAMPLING UNIT}

One of the units into which an aggregate is divided for the sampling, each unit being regarded as individual and indivisible when the section is made.

Percentage refers to a special kind of ratio percentage are used in making comparison between two or more series of data. Percentage is used to describe the relationship and also be used to compare relative terms of two or more series of data.[14]-18]

\section{RESULTS \& DISCUSSION}

\section{Purchase behavior/usage and attitude of customers}

It is inferred that majority customers make the purchase decision themselves and are influenced by friends and advertisements. The main purpose behind the purchase is school use, followed by hangouts and market use.

It is inferred that $52 \%$ of the customers owning BSA cycles have been driving for nearly 4 years, which shows the durability of the cycle and the satisfaction that he gets from his cycle. The satisfaction level can be measured by the amount of time he spend riding per day which leads to $50 \%$ customers riding nearly 2 hours per day.[19]-[25]

\section{E.Brand perception and brand image of customers.}

It is inferred that regarding brand perception and image 118 respondents feel that it is the fastest bicycle on the road, 100 respondents feel that the cycle is long lasting, 66feel it is a premium brand, 49 feel it is the best design, 30 feel the cycle resembles a celebrity. It is recommended that the company keep up these images in future production and try to improve in the other fields like best design long lasting, etc.

\section{F.Brand awareness of customers.}

It is inferred that 154 respondents are aware of the brand through friends and relatives, newspaper and television has 55 respondents, posters and banners has 39 respondents, showroom displays only cover 18 , which shows that word or mouth advertisement plays a big role in purchase.

It is inferred that $84 \%$ of the customers have viewed the advertisement plays a major role in promoting brand awareness among the customers.

\section{G.Other Findings}

1. This study finds that BSA Ladybird is the leading brand in the market followed by the other manufacturers like HERO and ATLAS.

2. About $72 \%$ of dealers expressed their opinion that overall market for Ladybird Cycle as Good.

3. Among all the brands BSA LADYBIRD range is found to be high in sales as it posses good quality, normal price, visual appeal and flexible.
4. As far as Availability of the product is concerned BSA LADYBIRD is found to be available more when compared to that of the other manufacturers

5. It has been inferred that $64 \%$ of the dealers receive complaints from the customers, which are mainly Breakage of parts, manufacturing defects and non-availability of spares.

6. Most of the manufacturers do not offer more than THREE year Warranty or Guarantee for their cycles. The Guarantee carries on major spares viz., Frame, Fork, Mudguards etc., and not covers on plastic, rubber parts.

7. The service has to be provided only by the dealers when the complaints are received. There is no concept of annual or periodic maintenance.

8. It has been found that no manufacturers are good at advertising or marketing. Only a few advertise for their products between long intervals of time.

9. The dealers are giving their own advertisement so as to increase the sales of the LADYBIRD Cycle.

10. When dealers asked for the recommendations for a particular brand $66 \%$ of the dealers recommended Hero as it posses good quality, normal price, highly flexible and available in the market easily.

11. Dealers suggestion for a new brand is that it should be of good quality, flexible, normal price, more attractive and should posses additional features and advertisement support in order to make it familiar in the market.

It has been found there is a connection among sellers ' understanding in their sector and the average number of Ladybird Cycles sold in a month.

12. There is also a significant relationship between the dealers experience and the dealers recommendation for a particular brand.

\section{SUGGESTIONS}

In order to over come intensity of competition not from bicycle sectors but also from the two wheelers automobiles the company has to increase the frequency of advertisement and provide promotional activities.

It is advisable to the company to incorporate the cycling concept when mass communications. This should capture " pollution free bike" or "Save fuel" or " good for health " etc.,

Company could create Retail concept awareness among the customers with the help of mailing system to reach the customers.

The Company bring in better and new models according to customer taste in frequent intervals of time. Delayed intervals in introduction of new models will make an advantageous path for competitors to seize the market share.

The company should provide necessary training to staff in outlets regarding latest introductions, e.g.: Lady Bird LX, as mentioned before many customers know the name Lady Bird LX but they do not know the advantages. It is suggested company should take necessary measures to improve model knowledge by means of mass communication.

The company should provide better service to various outlets, by proper delivery, producing

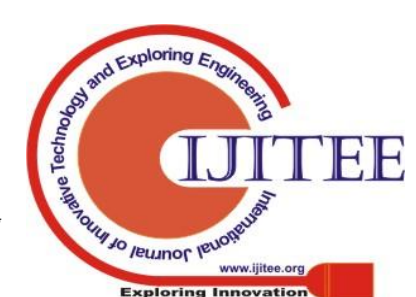


brochures and catalogues whenever needed, and give proper training.

The company should help bring more exclusive outlets, which will be convenient for customers to reach to. The company should help improve the infrastructure of the outlets so that it satisfies the customers.

\section{CONCLUSION}

A conclusion section is not required. Although a conclusion may review the main points of the paper, do not replicate the abstract as the conclusion. A conclusion might elaborate on the importance of the work or suggest applications and extensions.

\section{REFERENCES}

1. Vasanthi, S. \& Rabiyathul Basariya, S. 2019, "Influence of value analysis and cross training in industry", International Journal of Engineering and Advanced Technology, vol. 8, no. 6, pp. 1810-1811.

2. Velvizhi, R., Sri Gowtham, S. \& Jeya Priya, D. 2019, "Examination of early feedbacks for effective product retailing on E-commerce websites", International Journal of Engineering and Advanced Technology, vol. 8, no. 6 Special Issue 2, pp. 703-706.

3. Anuradha, C., Pothumani, S. \& Kavitha, R. 2019, "A novel method towards E-commerce", International Journal of Engineering and Advanced Technology, vol. 8, no. 6 Special Issue 2, pp. 535-538.

4. Thomas, J. \& Rabiyathul Basariya, S. 2019, "A study on the issues of financial ratio analysis", Indian Journal of Public Health Research and Development, vol. 10, no. 3, pp. 1079-1081.

5. Ramachandran, S. \& Rabiyathul Basariya, S. 2019, "Online marketing - study on customer satisfaction and relationship", Indian Journal of Public Health Research and Development, vol. 10, no. 3, pp. 1072-1078.

6. Priya, R., Vinothini, G. \& Cor Jesu, C.D. 2019, "The mentor-protégé relationship for professional growth", Journal of Advanced Research in Dynamical and Control Systems, vol. 11, no. 9 Special Issue, pp. 1110-1119.

7. Jannifer Rani, N., Bina Pani, S. \& Nimisha, N.S. 2019, "A study on money back polices available in LIC", Journal of Advanced Research in Dynamical and Control Systems, vol. 11, no. 9 Special Issue, pp. 833-839

8. Saillaja, V., Jhansi Rani, K. \& Catherine, R. 2019, "Global marketing management planning and organization", Journal of Advanced Research in Dynamical and Control Systems, vol. 11, no. 9 Special Issue, pp. 489-493.

9. Saillaja, V., Jhansi Rani, K. \& Catherine, R. 2019, "The new phase of marketing information system", Journal of Advanced Research in Dynamical and Control Systems, vol. 11, no. 9 Special Issue, pp. 482-488.

10. Thoufiqulla \& Raju, D.V. 2019, "Perception of indian investor towards investment in mutual funds with special reference to mip funds", Journal of Advanced Research in Dynamical and Control Systems, vol. 11, no. 5, pp. 177-183.

11. Jasmine, K.R.M. \& Basariya, S.R. 2018, "A study on the customers benefits on mutual funds", International Journal of Civil Engineering and Technology, vol. 9, no. 4, pp. 45-48.

12. Vasanthi, S. \& Basariya, S.R. 2019, "Pros and cons of on the job training versus off the job training", International Journal of Scientific and Technology Research, vol. 8, no. 10, pp. 671-674.

13. Pavithra, J. \& Ganesan, M. 2016, "A study on awareness and impact of micro-financial schemes", International Journal of Applied Business and Economic Research, vol. 14, no. 8, pp. 5449-5460.

14. Pavithra, J., Dilli Babu, P. \& Ambuli, T.V. 2014, "A study on budgetary control at Maruti Service Masters, Chennai", International Journal of Applied Business and Economic Research, vol. 12, no. 2, pp. 151-161.

15. Gunaraja, T.M. \& Venkatrama Raju, D. 2018, "Determining factors of organisational climate with reference to leadership styles", International Journal of Mechanical Engineering and Technology, vol. 9, no. 9, pp. 1327-1332.

16. Gunaraja, T.M. \& Venkatrama Raju, D. 2018, "The role of job satisfaction and training of employees in determining organisational climate of a selected industry", International Journal of Civil Engineering and Technology, vol. 9, no. 8, pp. 1266-1269.

17. Aarathy, T.S. \& Raju, D.V. 2018, "Performance appraisal and its effects on employees with respect to it sector in Chennai city", International Journal of Civil Engineering and Technology, vol. 9, no. 6, pp. 1535-1538.

18. Aarathy, T.S. \& Raju, D.V. 2018, "Employee perception towards performance appraisal system in IT sector", International Journal of Mechanical Engineering and Technology, vol. 9, no. 5, pp. 131-135.

19. Porselvi, W., Jublee, D. \& Sivanesan, G. 2018, "A study on factors influencing adoption of technology and innovation in banking industry, tamilnadu, India", International Journal of Mechanical Engineering and Technology, vol. 9, no. 5, pp. 789-800.

20. Akessa, G.M. and Dhufera, A.G., 2015. Factors That Influences Students Academic Performance: A Case of Rift Valley University, Jimma, Ethiopia. Journal of Education and Practice, 6(22), pp.55-63.

21. Miller, G. and Shih, C.C., 1999. A faculty assessment of the academic rigor of on-and off-campus courses in agriculture. Journal of Agricultural Education, 40, pp.57-65.

22. Tsinidou, M., Gerogiannis, V. and Fitsilis, P., 2010. Evaluation of the factors that determine quality in higher education: an empirical study. Quality Assurance in education, 18(3), pp.227-244.

23. Farooq, M.S., Chaudhry, A.H., Shafiq, M. and Berhanu, G., 2011. Factors affecting students' quality of academic performance: a case of secondary school level. Journal of quality and technology management, 7(2), pp.1-14.

24. Fitsilis, P., Gerogiannis, V. and Anthopoulos, L., 2014. Ontologies for software project management: a review. Journal of Software Engineering and Applications, 7(13), p.1096.

25. Adams, J.D. and Jaffe, A.B., 1996. Bounding the effects of R\&D: an investigation using matched establishment-firm data(No. w5544). National bureau of economic research.

\section{AUTHORS PROFILE}

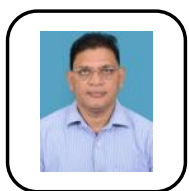

D. Venkatrama Raju, Professor \& Head, Department Of Science \& Humanities, Bharath Institution Of Higher Education And Research TamilNadu,India

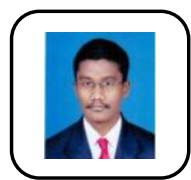

J. Kannan, Associate Professor, Department Of Science \& Humanities,Bharath Institution Of Higher Education And Research TamilNadu,India 